\title{
Water quality assessment of lake water: a review
}

\author{
Rachna Bhateria $^{1} \cdot$ Disha Jain $^{1}$
}

Received: 23 March 2015/ Accepted: 4 August 2015/Published online: 24 March 2016

(C) Springer International Publishing 2016

\begin{abstract}
Ever increasing population, urbanization and modernization are posing problems of sewage disposal and contamination of surface waters like lakes. Natural water gets contaminated due to weathering of rocks, leaching of soils and mining processing, etc. Various types of problems in lake which cause nutrient enrichment in lake have been reviewed. Land use change and longer growing seasons could increase the use of fertilizers with subsequent leaching to watercourses, rivers and lakes, increasing the risk of eutrophication and loss of biodiversity. Water quality can be assessed by various parameters such as $\mathrm{BOD}$, temperature, electrical conductivity, nitrate, phosphorus, potassium, dissolved oxygen, etc. Heavy metals such as $\mathrm{Pb}, \mathrm{Cr}, \mathrm{Fe}, \mathrm{Hg}$, etc. are of special concern because they produce water or chronic poisoning in aquatic animals. Harmful algal blooms are becoming increasingly common in freshwater ecosystems globally. Pollution by plastic debris is an increasing environmental concern in water bodies, where it affects open-water, shoreline and benthic environments. Surface water densities of plastics are as high as those reported for areas of litter accumulation within oceanic gyres. Different methods have been used to analyse the water quality of lake such as Hyperion, water quality index and hazard quotient. It is recommended that pollution prevention and water re-use should be adopted in combination with the recycling of nutrients in controlled urban agriculture.
\end{abstract}

Disha Jain

jaindisha11@gmail.com

1 Department of Environmental Sciences, Maharshi Dayanand University, Rohtak, Haryana, India
Keywords Hyperion P Plastic debris $\cdot$ Sewage $\cdot$ Algal blooms · Hazard quotient · Urbanization

\section{Introduction}

Lakes are inland bodies of water that lack any direct exchange with an ocean. Lake ecosystems are made up of physical, chemical and biological properties contained within these water bodies. Lakes may contain fresh or salt water (in arid regions). They may be shallow or deep, permanent or temporary. Lakes of all types share many ecological and biogeochemical processes and their study falls within the discipline of 'limnology'. Lakes are superb habitats for the study of ecosystem dynamics: interactions among biological, chemical and physical processes are frequently either quantitatively or qualitatively distinct from those on land or in air. Because the boundaries between water and land and water and air are distinct, there is tight coupling among many ecosystem components. The isolated lakes are saline due to evaporation or groundwater inputs. Depending on its origin, a lake may occur anywhere within a river basin. A headwater lake has no single river input but is maintained by inflow from many small tributary streams, by direct surface rainfall and by groundwater inflow. Such lakes almost invariably have a single river output. Further downstream in river basins, lakes have a major input and one major output, with the water balance from input to output varying as a function of additional sources of water. Although lakes contain $50.01 \%$ of all the water on the Earth's surface, they hold $49.8 \%$ of the liquid surface freshwater. Many organisms depend on freshwater for survival and humans frequently depend on lakes for a great many 'goods and services' such as drinking water, waste removal, fisheries, agricultural irrigation, industrial 
activity and recreation. For these reasons lakes are important ecosystems (Fig. 1).

\section{Lake zonation}

Lakes normally consist of four distinct zones which provide a variety of ecological niches for different species of plant and animal life. These zones are:

\section{Littoral zone}

The shallow, nutrient-rich waters near the shore, contain rooted aquatic plants and an abundance of other forms of aquatic life.

\section{Limnetic zone}

The open-water surface layer receives sufficient sunlight for photosynthesis and contains varying amounts of floating phytoplankton, plant-eating zooplankton and fish, depending on the availability of plant nutrients.

\section{Profundal zone}

This zone of deep water not penetrated by sunlight is inhabited mostly by fish, such as bass and trout that are adapted to its cooler, darker water and lower levels of dissolved oxygen.

\section{Benthic zone}

This zone is deepest and located at the bottom of the lake is inhabited primarily by large numbers of bacteria, fungi, bloodworms and other decomposers which live on dead

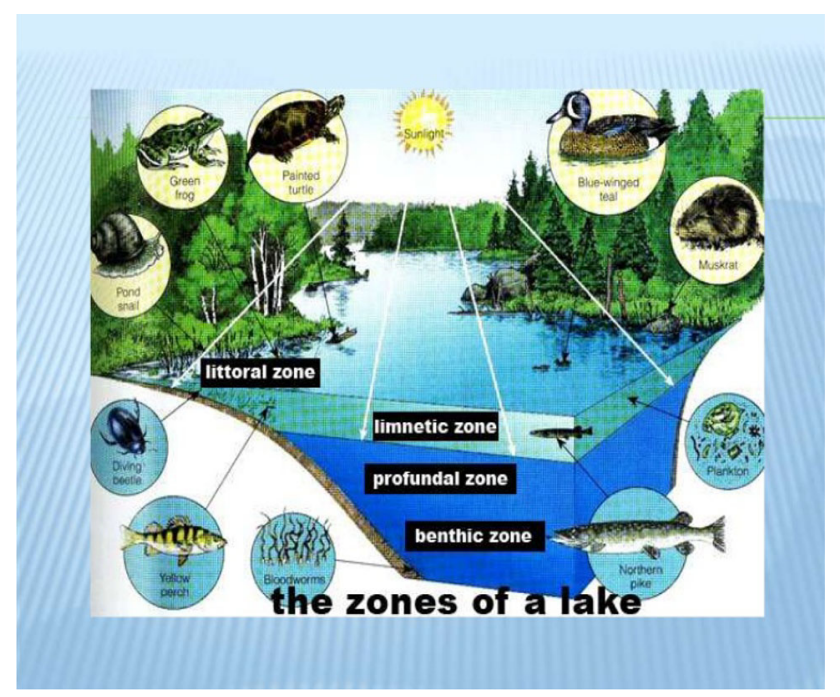

Fig. 1 Zonation of a lake plant debris, animal remains and animal wastes that float down from above.

\section{Origin of lakes}

Lakes are ephemeral. They originate as a product of geological processes and terminate as a result of the loss of the ponding mechanism, by evaporation caused by changes in the hydrological balance, or by in filling caused by sedimentation. The mechanisms of origin are numerous and are reviewed by (Chapman 1996), who differentiated 11 major lake types, sub-divided into 76 sub-types.

\section{Glacial lakes}

Lakes on or in ice, ponded by ice or occurring in icescraped rock basins belong to this type. The latter origin (glacial scour lakes) contains the most lakes. Lakes formed by moraines of all types and kettle lakes occurring in glacial drift also come under this category (MOEF 2010), e.g. Chandratal in Himachal Pradesh.

\section{Tectonic lakes}

Lakes formed by large-scale crustal movements separating water bodies from the sea, e.g., Lake Tso Moriri and Pangong Tso in Ladakh.

\section{Fluvial lakes}

Lakes created by river meanders in flood plains such as oxbow and levee lakes and lakes formed by fluvial damming due to sediment deposition by tributaries, e.g., Kabartal in Bihar, Surahatal in Uttar Pradesh (Chandra et al. 2012).

\section{Shoreline lakes}

Lakes cut off from the sea by the creation of spits caused by sediment accretion due to long-shore sediment movement, such as for the coastal lakes of Egypt.

\section{Dammed lake}

Lakes created behind rock slides, mud flows and screes. These are lakes of short duration but are of considerable importance in mountainous regions.

\section{Volcanic lakes}

Lakes occurring in craters and calderas and which include dammed lakes resulting from volcanic activity. 


\section{Solution lakes}

Lakes occurring in cavities created by percolating water in water-soluble rocks such as limestone, gypsum and rock salt. They are normally called Karst lakes and are very common in the appropriate geological terrain. They tend to be considered as small, although there is some evidence that some large water bodies may have originated in this way (e.g. Lake Ohrid, Yugoslavia).

\section{Meteorite}

Lakes formed in the craters developed due to the impact of meteorites (e.g. Lake Lonar in Aurangabad).

\section{Classification of lakes}

Lakes are classified on the basis of their water chemistry. Based on the levels of salinity, they are known as freshwater, brackish or saline lakes. On the basis of their nutrient content. These are divided into four types:

\section{Oligotrophic}

A lake with low primary productivity, the result of low nutrient content. These lakes have low algal production and consequently, often have very clear waters, with high drinking water quality.

\section{Mesotrophic}

Lakes with an intermediate level of productivity. These lakes are commonly clear water lakes and ponds with beds of submerged aquatic plants and medium levels of nutrients.

\section{Eutrophic}

Due to excessive nutrients, especially nitrogen and phosphorus, these water bodies are able to support an abundance of aquatic plants. Usually the water body will be dominated either by aquatic plants or algae. When aquatic plants dominate the water tends to be clear. When algae dominate the water tends to be darker. The algae engage in photosynthesis which supplies oxygen to the fish and biota which inhabit these waters. Occasionally an excessive algae bloom will occur and can ultimately result in fish kills due to respiration by algae and bottom living bacteria. The process of eutrophication can occur naturally and by human impact on the environment.

\section{Hypereutrophic}

These lakes are highly nutrient-rich lakes characterized by frequent and severe nuisance algal blooms and low transparency. Hypereutrophic lakes have a visibility depth of less than 3 feet; they have greater than $40 \mu \mathrm{g} / \mathrm{l}$ total chlorophyll and greater than $100 \mu \mathrm{g} / \mathrm{l}$ phosphorus. The excessive algal blooms can also significantly reduce oxygen levels and prevent life from functioning at lower depths creating dead zones beneath the surface.

\section{Physico-chemical parameters}

It is very essential and important to test the water before it is used for drinking, domestic, agricultural or industrial purpose. Water must be tested with different physicochemical parameters. Water does contain different types of floating, dissolved, suspended and microbiological as well as bacteriological impurities. Some physical test should be performed for testing of its physical appearance such as temperature, $\mathrm{pH}$, turbidity, TDS, etc., while chemical tests should be perform for its BOD, COD, dissolved oxygen, alkalinity, hardness and other characters.

\section{Temperature}

In an established system the water temperature controls the rate of all chemical reactions and affects fish growth, reproduction and immunity. Drastic temperature changes can be fatal to fish. The rates of biological and chemical processes depend on temperature. Aquatic organisms from microbes to fish are dependent on certain temperature ranges for their optimal health. Temperature affects the oxygen content of the water (oxygen levels become lower as temperature increases); the rate of photosynthesis by aquatic plants; the metabolic rates of aquatic organisms; and the sensitivity of organisms to toxic wastes, parasites and diseases. Causes of temperature change include weather, removal of shading stream bank vegetation, impoundments, discharge of cooling water, urban storm water and groundwater inflows to the stream (Spellman and Drinan 2012).

\section{$p H$}

$\mathrm{pH}$ is most important in determining the corrosive nature of water. Lower the $\mathrm{pH}$ value higher is the corrosive nature of water. The reduced rate of photosynthetic activity and the assimilation of carbon dioxide and bicarbonates are ultimately responsible for increased $\mathrm{pH}$ the low oxygen values coincided with high temperature during the summer month. 
Various factors bring about changes in the $\mathrm{pH}$ of water. The higher $\mathrm{pH}$ values observed suggests that carbon dioxide, carbonate-bicarbonate equilibrium is affected more due to change in physico-chemical condition.

\section{EC (electrical conductivity)}

Conductivity shows significant correlation with parameters such as temperature, $\mathrm{pH}$ value alkalinity, total hardness, calcium, total solids, total dissolved solids and chemical oxygen demand chloride and iron concentration of water. Conductivity in streams and rivers is affected primarily by the geology of the area through which the water flows. Streams that run through areas with granite bedrock tend to have lower conductivity because granite is composed of more inert materials that do not ionize (dissolve into ionic components) when washed into the water (Gupta and Paul 2010). Streams that run through areas with clay soils tend to have higher conductivity because of the presence of materials that ionize when washed into the water. Ground water inflows can have the same effects depending on the bedrock they flow through. Discharges to streams can change the conductivity depending on their make-up. A failing sewage system would raise the conductivity because of the presence of chloride, phosphate and nitrate; an oil spill would lower the conductivity.

\section{Biochemical oxygen demand (BOD)}

BOD is a measure of the dissolved oxygen consumed by microorganisms during the oxidation of reduced substances in waters and wastes. BOD directly affects the amount of dissolved oxygen in rivers and streams. The greater the $\mathrm{BOD}$, the more rapidly oxygen is depleted in the stream. This means less oxygen is available to higher forms of aquatic life. The consequences of high BOD are the same as those for low dissolved oxygen aquatic organisms which become stressed, suffocate and die. Sources of BOD include leaves and woody debris; dead plants and animals; animal manure; effluents from pulp and paper mills, wastewater treatment plants, feedlots and food-processing plants; failing septic systems; and urban storm water runoff. The discharge of wastes with high levels of BOD can cause water quality problems such as severe dissolved oxygen depletion and fish kills in the receiving water bodies (Penn et al. 2003). Chlorine can also affect BOD measurement by inhibiting or killing the microorganisms that decompose the organic and inorganic matter in a sample. In chlorinated waters, such as those below the effluent from a sewage treatment plant, it is necessary to neutralize the chlorine with sodium thiosulphate (APHA 2005).

\section{Sulphate}

Sulphate ions usually occur in natural waters. Many sulphate compounds are readily soluble in water. Most of them originate from the oxidation of sulphate ores, the solution of gypsum and anhydrite, the presence of shale, particularly those rich in organic compounds and the existence of industrial wastes. Atmospheric sulphur dioxide formed by the combustion of fossil fuels and emitted by the metallurgical roasting processes may also contribute to the sulphate compounds of water. Sulphur trioxide $\left(\mathrm{SO}_{3}\right)$ produced by the photolytic oxidation of sulphur dioxide comes with water vapours to form sulphuric acid which is precipitated as acid rain or snow. Sulphur-bearing mineral are common in most sedimentary rocks. In the weathering process, gypsum (calcium sulphate) is dissolved and sulphide minerals are partly oxidized, giving rise to a soluble form of sulphate that is carried away by water. In humid region, sulphate is readily leached from the zone of weathering by infiltrating waters and surface run off but in semiarid and arid regions the soluble salts may accumulate within a few tens of feet of land surface (APHA 2005).

\section{Calcium}

Calcium, in the form of the $\mathrm{Ca}^{2+}$ ion, is one of the major inorganic cations, or positive ions, in saltwater and freshwater. It can originate from the dissociation of salts, such as calcium chloride or calcium sulphate, in water. Most calcium in surface water comes from streams flowing over limestone, $\mathrm{CaCO}_{3}$, gypsum, $\mathrm{CaSO}_{4} \cdot 2 \mathrm{H}_{2} \mathrm{O}$ and other calcium-containing rocks and minerals. Calcium carbonate is relatively insoluble in water, but dissolves more readily in water containing significant levels of dissolved carbon dioxide. The concentration of calcium ions $\left(\mathrm{Ca}^{2+}\right)$ in freshwater is found in a range of 0 to $100 \mathrm{mg} / \mathrm{L}$ and usually has the highest concentration of any freshwater cation (Abboud 2014). A level of $50 \mathrm{mg} / \mathrm{L}$ is recommended as the upper limit for drinking water. High levels are not considered a health concern; however, levels above $50 \mathrm{mg} / \mathrm{L}$ can be problematic due to formation of excess calcium carbonate deposits in plumbing or in decreased cleansing action of soaps. If the calcium ion concentration in freshwater drops below $5 \mathrm{mg} / \mathrm{L}$, it can support only sparse plant and animal life, a condition known as oligotrophic. Typical seawater contains $\mathrm{Ca}^{2+}$ levels of about $400 \mathrm{mg} / \mathrm{L}$.

\section{Magnesium}

It is also measured by complex metric titration with standard solution of EDTA using Eriochrome black $\mathrm{T}$ as indicator under the buffer conditions of $\mathrm{pH}$ 10.0. The common aqueous species is $\mathrm{Mg}^{2+}$. The carbonate 
equilibrium reactions for magnesium are more complicated than for calcium and conditions for direct precipitation of dolomite in natural waters are not common. Important contributors to the hardness of a water, magnesium salts break down when heated, forming scale in boilers. Chemical softening, reverse osmosis, or ion exchange reduces magnesium and associated hardness to acceptable levels. Magnesium is an essential element in chlorophyll and in red blood cells. Some salts of magnesium are toxic by ingestion or inhalation. Concentrations greater than $125 \mathrm{mg} / \mathrm{L}$ also can have a cathartic and diuretic effect (APHA 2005).

\section{Sodium and potassium}

It is measured with the help of flame photometer. The instrument is standardized with the known concentration of sodium ion (1 to $100 \mathrm{mg} / \mathrm{l}$ ) and concentration of potassium ion (1 to $5 \mathrm{mg} / \mathrm{l})$. Relatively high concentrations may be found in brines and hard water softened by the sodium exchange process. The ratio of sodium to total cations is important in agriculture and human pathology. Soil permeability can be harmed by a high sodium ratio. Persons afflicted with certain diseases require water with low sodium concentration. Sodium can be removed by the hydrogen-exchange process or by distillation. Potassium is an essential element in both plant and human nutrition and occurs in groundwater as a result of mineral dissolution (APHA 2005).

\section{Phosphorus}

Phosphorus is an essential nutrient for the plants and animals that make up the aquatic food web. Since phosphorus is the nutrient in short supply in most fresh waters, even a modest increase in phosphorus can, under the right conditions, set off a whole chain of undesirable events in a stream including accelerated plant growth, algae blooms, low dissolved oxygen and the death of certain fish, invertebrates and other aquatic animals. There are many sources of phosphorus, both natural and human. These include soil and rocks, wastewater treatment plants, runoff from fertilized lawns and cropland, failing septic systems, runoff from animal manure storage areas, disturbed land areas, drained wetlands, water treatment and commercial cleaning preparations. Phosphorus has a complicated story. Pure, "elemental" phosphorus $(\mathrm{P})$ is rare. In nature, phosphorus usually exists as part of a phosphate molecule $\left(\mathrm{PO}_{4}\right)$. Phosphorus in aquatic systems occurs as organic phosphate and inorganic phosphate. Organic phosphate consists of a phosphate molecule associated with a carbon-based molecule, as in plant or animal tissue. Phosphate that is not associated with organic material is inorganic. Inorganic phosphorus is the form required by plants. Animals can use either organic or inorganic phosphate. Both organic and inorganic phosphorus can either be dissolved in the water or suspended attached to particles in the water column (Spellman 2014).

\section{Nitrate and ammonia}

Both nitrate $\left(\mathrm{NO}_{3}-\mathrm{N}\right)$ and ammonia $\left(\mathrm{NH}_{4}-\mathrm{N}\right)$ concentrations are highly variable during lake seasonal cycles. For deep stratified lakes, nitrate is higher during mixing events and usually decreases in late summer and fall. For the trophogenic zone of shallow lakes, both concentrations would be lower during periods of water column stability and they will increase during vertical mixing events. $\mathrm{NH}_{4}$ $\mathrm{N}$ is generated by heterotrophic bacteria as the primary nitrogenous end product of decomposition of organic matter and is readily assimilated by plants in the trophogenic zone (Wetzel 2001). $\mathrm{NH}_{4}-\mathrm{N}$ concentrations are usually low in oxygenated waters of oligotrophic to mesotrophic deep lakes because of utilization by plants in the photic zone and nitrification to $\mathrm{N}$ oxidized forms. At relatively low dissolved oxygen, nitrification of ammonia ceases, the absorptive capacity of the sediments is reduced and a marked increase of the release of $\mathrm{NH}_{4}-\mathrm{N}$ from the sediments then occurs.

\section{TDS and TSS}

Solids are found in streams in three forms, suspended, volatile and dissolved. Suspended solids include silt, stirred-up bottom sediment, decaying plant matter, or sewagetreatment effluent. Suspended solids will not pass through a filter, whereas dissolved solids will. The TDS concentration in a body of water is affected by various factors (APHA 2005). Fertilizers from fields and lawns can add a variety of ions to a stream. Increases in TDS can also result from runoff from roads that have been salted in the winter. Organic matter from wastewater treatment plants may contribute higher levels of nitrate or phosphate ions. If TDS levels are high, especially due to dissolved salts, many forms of aquatic life are affected. The salts act to dehydrate the skin of animals. TDS values in lakes and streams are typically found to be in the range of 50 to $250 \mathrm{mg} / \mathrm{L}$. In areas of especially hard water or high salinity, TDS values may be as high as $500 \mathrm{mg} / \mathrm{L}$. Volatile solids are those solids in water or other liquids that are lost on ignition of dry solids at $1020^{\circ} \mathrm{F}\left(550{ }^{\circ} \mathrm{C}\right)$. It is a water quality measure obtained from the loss on ignition of total suspended solids. It has great importance in water and wastewater treatment. It normally represents the amount of organic solids in water. It is helpful in assessing the amount biologically inert organic matter, such as lignin in case of 
wood pulping waste liquids. A volatile solid is a substance that can easily transform from its solid phase to vapour phase without going through a liquid phase. In domestic wastewater, solids are about 50 percent organic, which in turn contaminates the ground and fresh water. These solids are generally from plants, dead animal matter and synthetic organic compounds. They can be ignited or burned. Because the organic fraction can be driven off at high temperatures, they are called volatile solids.

\section{Threats to urban water bodies}

For over thousands of years, human settlements and civilizations have originated, concentrated and thrived around different types of water bodies. It is known that water bodies have played a crucial role in growth and development of human society. However, it is paradoxical that they have undergone degradation in modern times due to various anthropogenic activities. These are pollution, encroachment, eutrophication, illegal mining activities, ungoverned tourist activities and cultural misuse.

\section{Pollution}

All urban water bodies in India are suffering because of water pollution. Some of the pollutants like lead $(\mathrm{Pb})$, arsenic (As), mercury $(\mathrm{Hg})$, chromium $(\mathrm{Cr})$ specially hexavalent chromium, nickel $(\mathrm{Ni})$, barium $(\mathrm{Ba})$, cadmium $(\mathrm{Cd})$, cobalt $(\mathrm{Co})$, selenium (Se), vanadium $(\mathrm{V})$, oils and grease, pesticides, etc. are very harmful, toxic and poisonous even in ppb (parts per billion) range. There are some minerals which are useful for human and animal health in small doses beyond which these are toxic. Zinc $(\mathrm{Zn})$, copper $(\mathrm{Cu})$, iron $(\mathrm{Fe})$, etc. fall into this category. For agriculture, some elements like zinc, copper, manganese (Mn), sulphur (S), iron, boron (B), together with phosphates, nitrates, urea, potassium, etc. are useful in prescribed quantities. There are some compounds like cyanides, thiocyanides, phenolic compounds, fluorides, radioactive substances, etc. which are harmful for humans as well as animals. In India, water pollution due to industrial wastes and sewage has been assuming menacing proportions pollution. Large lakes and large stretches of most of the rivers in India have water which is unsafe for drinking purpose.

\section{Encroachment}

Encroachment is another major threat to water bodies particularly in urban areas. As more people are migrating to cities the availability of land is getting scarce. Hence, these urban water bodies are no more acknowledged for their ecosystem services but as real estate (CSE 2006). Both for the government and the private builders these lakes are extremely valuable opportunities. Charkop Lake in Maharashtra, Ouster Lake in Puducherry and Deepor beel in Guwahati are well-known examples of encroachment.

\section{Illegal mining activities}

Illegal mining for building material such as sand and stones both on the catchment and on the bed of the lake also have extremely damaging impact on the water body and one the reasons behind the destruction of many water bodies in India. For example, the Basamand Lake in Jodhpur, once the only source of drinking water for the city of Jodhpur, has been suffering from illegal mining for the last 20 years despite the court's order to stop mining in 1999 (CSE 2006). Surajkund Lake in Haryana is another example of illegal mining activities that have destroyed the lake.

\section{Unplanned tourism activities}

Unplanned tourism activities without systematic planning and regulation proved to be another major threat to urban water bodies. Dal Lake in Srinagar, Tso Morari and Pong Lakes in Ladakh are examples where the unplanned and unregulated tourism has posed long-term negative impacts both on biodiversity of the area as well as on the local environment.

\section{Catchment area of lake}

Researchers studied about Sukhna Lake that is at the Shivalik foot hills are one of the seven most degraded ecosystems of India. These low hills of recent origin are made up of one of the most erodible soils of the world. In the last 400 years, the vegetative cover of the hills has been destroyed by human activities resulting in significant mass soil erosion in the monsoon period (Bhargave et al. 2013). Low productivity, poor vegetative cover, high runoffs, soil loss and presence of deep and wide network of gullies are the main characteristics in the upper catchment of the lake. All these factors are responsible for the heavy siltation of the Sukhna Lake. Different parent materials, namely sand stone and shale occur side by side; their differential hydrothermal properties and erosion behaviour give rise to lack of cohesion causing heavy runoffs from the bare hill slopes. Manu Bhatnagar in 2008 studied that the three storm water channels lie on the upstream side of the Hauz Khas in New Delhi, India. These channels emerge south of the hauz from the southern ridge area and serve a catchment. Currently, these channels are carrying wastewaters/ sewage from unsewered areas of the now heavily urbanized 
catchment most notably from Katwaria Sarai village and Munirka Village in New Delhi, India.

\section{Plankton in lakes}

Plankton is important members of the aquatic food web. The plankton includes phytoplankton or algae (microscopic plants) and zooplankton (tiny shrimp-like animals that eat algae). The phytoplankton is primary producers that convert light energy from the Sun to plant tissue through the process of photosynthesis. Phytoplankton composition is a tropic indication of the water mass. In addition, phytoplankton species are used as an indicator for determining the nutrient level which is the basis for preparing and monitoring the strategies of the lake management in the lakes. The cyanobacteria are of particular interest to limnologists and lake users because members of this group are those that often form nuisance blooms and their dominance in lakes may indicate poor water conditions. Some species of cyanobacteria are known to produce toxins (Fakioglu 2013). In the works related with phytoplankton communities used for predicting the ecological structure of aquatic systems, it has been tried to develop functional groups by improving the systematic investigation. Furthermore, some indices were developed according to numerical and biovolume values of phytoplankton (Palmer Index (1969), Descy Index (1979), TDI Index (1995), etc.). HPLC pigment analysis is used for the diagnosis of phytoplankton species in recent years. In studies conducted in Lake Erie, samples have been collected in three different seasons such as spring, summer and rainfall for 5 years; 49 species were determined at the end of the study. In a lake with $25,000 \mathrm{~km}^{2}$ surface area, phytoplankton biomass showed local changes and it was determined as $1.88 \pm 0.12 \mathrm{~g} / \mathrm{m}^{3}$, $1.04 \pm 0.07 \mathrm{~g} / \mathrm{m}^{3}$ and $0.63 \pm 0.071 \mathrm{~g} / \mathrm{m}^{3}$ in west, mid and east part of the lake, respectively. It was determined that algal biomass decreased and biomasses of Aphanizomenon flos-aque, Stephanodiscus binderounus, S. niagarae, $S$. tenuis, Rhodomonas minuta decreased in the rate of 70-98 \% from 1970 to 1983-1987.

Seasonal changes of phytoplankton communities in Lake Managua are investigated, it is reported that bluegreen algae are dominant during the research period. In Lake Beysehir in Turkey, diatoms and green algae are found dominant throughout the research. Aulacoseira granulata and Cyclotella meneghiniana from centric diatom, Asterionella formosa, Cocconeis placentula, Cymbella affinis and Ulnaria acus from pennate diatoms, Monoraphidium spp., Mougeotia sp. and Scenedesmus linearis from Chlorophyta, Dinobryon divergens from
Chrysophyta and Cryptomonas marssonii, Rhodomonas lacustris from Cryptophyta, Merismopedia glauca from Cyanophyta are commonly found and partly numerical increases are observed. Phytoplankton biomass in the lake changes between $0.40 \pm 0.11 \mathrm{mg} / \mathrm{l}$ and $6.43 \pm 1.00 \mathrm{mg} / \mathrm{l}$. The lake is in mesotrophic nutrients level according to average phytoplankton biomass $(1.98 \pm 0.2 \mathrm{mg} / \mathrm{l})$ and it falls in good ecological quality class.

\section{Impacts of climate change on water quality of lake}

Potential impacts on surface water bodies, such as rivers and lakes, in terms of their hydrological regimes, hydromorphology, nutrient status, mobilization of toxic substances and acidification potential. Second, long-term changes in the water quality for specific aspects of freshwater environment such as estuaries and urban areas. Williams et al. (2000) showed that large diurnal variations in streams dominated by macrophytes occur and thus pollution events in such streams could also generate low DO levels. Under reduced flows in summer, BOD and phosphorus levels would increase, whereas ammonia levels would fall due to higher nitrification rates. This gives rise to increased nitrate concentrations as ammonia decays to nitrate. There could be enhanced growth of algal blooms in lakes which could affect DO levels and water supply. Also, with increased storm events, especially in summer, there could be more frequent incidences of combined sewer overflows discharging highly polluted waters into receiving water bodies, although there could be benefits in that storms will also flush away algal blooms. Small streams have shown an increase in winter temperature maxima in Scotland and there have been large increases in temperature reported for water courses in Scotland at all altitudes.

\section{Physical effects}

Changes in the precipitation regime that accompany climate change have the potential to cause shifts in the connectivity of lakes (with biological implications, e.g., for migratory fish species), as well as in erosion rates that could affect the inflow and outflow dynamics of lakes. The latter effects are particularly conspicuous in the tundra permafrost. Many thaw ponds (also called thermo karst ponds) on the Siberian and Alaska tundra are draining as a result of increased melting of the permafrost, while subarctic permafrost have begun to expand as a result of the differential melting of such soils. Ice-dammed lakes, e.g. those behind thick ice shelves (epishelf lakes), ice-jams on 
rivers, glacial dams and behind coastal sea ice barriers (stamukhi lakes) are prone to complete loss because of climate-dependent ice fracturing and collapse.

\section{Water balance}

Shifts in precipitation relative to evaporation (the $\mathrm{P} / \mathrm{E}$ ratio) cause changes in the water budget and hydraulic residence time of lakes, as well as in their depth and areal extent. Ponds and wetlands are especially vulnerable to changes in $\mathrm{P} / \mathrm{E}$ because of their shallow depths and large surface to volume ratio. For example, some rock basin ponds in the Canadian High Arctic have been drying up as a result of climate warming in the region, perhaps for the first time in millennia. Even large, shallow lakes can undergo major climate-driven fluctuations and loss. Lake Chad in northwestern Africa is less than 7-m deep and has responded greatly to changes in climate over the last few decades.

\section{Ice cover}

Many lakes in the North Temperate Zone are covered by ice and snow through much of the year. Climate warming is already showing an effect on such lakes by causing earlier dates of ice break-up and later dates of freeze-up. The 2007, Intergovernmental Panel on Climate Change report noted that for all available lake and river ice data over the last 150 years, the break-up date had become (mean_2SD) 6.5_1.2 days earlier per century, while the freeze-up date had occurred 5.8_1.6 days later per century. At polar latitudes, the earlier occurrence of rain instead of snow is likely to hasten the ice melting process, which is also affected by changes in the wind field.

\section{Chemical effects}

The hydraulic residence time of a lake (the time required to completely replace all water in a lake by its river, groundwater and rainfall inputs) affects the chemical composition of lake waters by controlling the time available for biogeochemical and photochemical processes to operate, the extent of accumulation, loss of dissolved and particulate materials and the duration of biogeochemical interactions with the lake sediments and littoral zone. In lakes that experience anoxic bottom water conditions and nutrient release from the sediments, a prolonged residence time caused by reduced precipitation and inflows can result in increased phosphorus accumulation (internal phosphorus loading) and eutrophication. Long-term studies at Toolik Lake Alaska have detected a doubling of alkalinity over time and this may be the result of climate-dependent increases in active layer depth in the permafrost that have exposed new soil material to weathering. Changes in precipitation may affect the magnitude of overland versus subterranean flow, thereby changing the nature and quantity of nutrient, major ion and dissolved organic carbon (DOC) inputs from different soil horizons to lakes. DOC loading is particularly responsive to climate change, through the leaching and erosion of soils (compounded by permafrost melting in the Polar Regions), changes in microbial transformation rates of particulate and dissolved organics and through changes in catchment vegetation.

\section{Biological effects}

Lake Tanganyika in Africa, the present trend of climate warming, decreased wind speeds and increased water column stability appears to have resulted in decreased nutrient supply to the euphotic zone by mixing, resulting in a $20 \%$ decrease in phytoplankton production. The consequences of this effect are serious given that a large portion of animal protein available to the surrounding human populations is derived from the pelagic fishery and this decrease in algal photosynthetic rates is estimated to have caused a $30 \%$ drop in fish yield.

\section{Photosynthetic communities}

A major climate change concern at temperate latitudes is the prospect of a shift in phytoplankton species composition toward dominance by species of cyanobacteria that form noxious blooms. These organisms create many water quality problems in lakes and a reservoir, including the release of taste and odour compounds, the production of various toxins and the overproduction of biomass that clogs water filters, disrupts zooplankton feeding and causes oxygen depletion. Bloom-forming cyanobacteria are likely to be favoured in a warming climate by several mechanisms (Mackay et al. 2006).

\section{Microbial communities}

Many lakes are net heterotrophic, with the respiration (R) of organic materials derived from autochthonous (within the lake) and allochthonous (outside the lake) sources exceeding photosynthesis (P). Heterotrophic microbial activity is likely to be enhanced in a warmer climate because of the direct physiological effects of temperature and in some environments by the increased availability of organic carbon and nutrients, e.g., from increased catchment runoff. The production and release of greenhouse gases from arctic thaw lakes has been identified as a potentially important feedback mechanism that will accelerate climate warming. 


\section{Plastic debris in lake}

Plastic litter is found in marine and freshwater ecosystems all around the globe. Plastic debris is variably classified according to size, origin, shape and composition. 'Microplastic debris' generally refers to plastic particles smaller than $5 \mathrm{~mm}$ (Arthur et al. 2009). The term 'micro plastic debris' is reserved for plastic particles smaller than $333 \mu \mathrm{m}$ that are retained on a $0.45-\mu \mathrm{m}$ pore size filter (Andrady 2011). Plastic debris larger than $5 \mathrm{~mm}$ is referred to as 'macroplastic debris'.

Plastic debris exhibits a wide range of shapes; in addition to recognizable plastic objects, the most common shapes are fragments, films, pellets, lines, fibres, filaments and granules. Plastic debris is often classified as either primary or secondary. Primary plastics are in their original or close-to-original form when collected, such as bottle caps, cigarette butts, microbeads or resin pellets. Secondary plastic debris encompasses the smaller pieces of plastic resulting from the breakdown of primary debris through various environmental degradation processes (Wagner et al. 2014). Macroplastics pose a health risk to aquatic animals, including fish, turtles and birds because of possible entanglement and ingestion (Boerger et al. 2010). Ingestion of plastic may cause internal bleeding, abrasion and ulcers, as well as blockage of the digestive tract (Wright et al. 2013). Plastic debris may act as a vector for contaminants, including persistent organic pollutants (POPs) and heavy metals Plastic debris in the environment will break down through a combination of photo and thermal oxidative degradation by ultraviolet (UV) radiation, mechanical weathering and biodegradation, but complete mineralization may not be possible or then only after hundreds or thousands of years (Shah et al. 2008). The breakdown products including microplastic and microscopic plastic debris create additional challenges.

As plastics degrade they can release toxic chemicals that were initially incorporated during their manufacturing to their surfaces in the environment. These chemicals include phthalates, alkyl phenols, biphenyl (BPA), heavy metals and polybrominated biphenyl ethers (PBDEs) (Bittner et al. 2014; Cheng et al. 2010; Teuten et al. 2007), which can disrupt endocrine functions and cause harmful reproductive and developmental effects in aquatic animals (Meeker et al. 2009). The trophic transfer of plastics along aquatic food webs has been verified, hence posing a health threat to aquatic ecosystems. The direct transfer of plastic-sorbed toxins to organisms through oral ingestion represents an additional hazard (Rochman et al. 2013; Ryan 1988).
Eriksen et al. (2013) collected debris in Lakes Superior, Huron and Erie using a manta trawl lined with a $333 \mu \mathrm{m}$ mesh size net. The surface water concentration of micro plastics extrapolated from the debris counts varied between 0 and 0.4663 items $/ \mathrm{m}^{2}$. Plastic debris included pellets, fragments, foam pieces, film and line.

Debris counts yielded concentrations of micro and macroplastic debris along the shorelines of Lakes superior, Huron and Erie between 0 and 34 items $/ \mathrm{m}^{2}$. However, whereas in Lake Huron, $93 \%$ of plastic debris was comprised of pellets, in Lakes Erie fragments were more abundant (Zbyszewski et al. 2014). In Lake Superior, cigarette filters were found to be a major source of shoreline accumulation of macroplastic debris (Hoellein et al. 2014). The surface textures of plastic debris samples from Lakes Huron and Erie have been examined by scanning electron microscopy (SEM) $78 \%$ and $37 \%$ of samples showed signs of mechanical and oxidative weathering, respectively (Zbyszewski et al. 2014).

The density of plastic debris may be altered by biofilm growth, which may cause otherwise buoyant debris to sink (Andrady 2011; Wright et al. 2013). Thus, population density alone cannot account for the differences in the concentrations of pelagic microplastic debris. This remains true even if we factor in the populations living in the watersheds of Lakes Superior, Michigan and Huron, which ultimately drain into Lake Erie. Pollution by plastic debris is an increasing environmental concern in the Laurentian Great Lakes is located in North America, where it affects open-water, shoreline and benthic environments. Openwater surveys reveal that, in certain areas of the Great Lakes, surface water densities of plastics are as high as those reported for areas of litter accumulation within oceanic gyres. Data from volunteer beach cleanups show that typically more than $80 \%$ of anthropogenic litter along the shorelines of the Great Lakes is comprised of plastics. The distribution of plastics in bottom sediments of the Great Lakes is essentially unknown. Sources of plastic debris to the Great Lakes include microplastic beads from consumer products, pellets from the plastic manufacturing industry and waste from beach-goers, shipping and fishing activities. Many plastics degrade slowly in the environment and may have long-term adverse ecological and economic impacts, including the dispersal of persistent organic pollutants. Plans to combat and curtail plastic debris pollution in the Great Lakes will come at a significant economic cost, likely in excess of $\$ 400$ million annually (Driedger et al. 2015). 


\section{Assessment of lake water using different methods}

\section{Hyperion}

Giardino et al. (2007) studied the water quality parameter (WQP) using Hyperion in Lake Garda. Hyperion imagery as a benchmark for moving towards operational use of RSrelated technologies that, integrated with traditional survey programmers, could provide useful information to implement the European Water Framework Directive (WFD). Within the WFD it is possible, for each water body, to monitor only the water quality elements most sensitive to a certain risk or pressure. For Lake Garda, this could be the deviation from a tropic level assessed with two causal elements (i.e., phosphorous and nitrogen) and with one response parameter, the chlorophyll- $a$ concentration. The Hyperion data processing presented in this study will be transferred to the assessment of lake water quality (mainly chlorophyll a) using more operational instruments (being a part of a technology validation/demonstration mission, Hyperion cannot be considered suitable for a long term monitoring). Large swath MODIS and MERIS sensors (both having the spectral bands used by MIM) offer almost-daily imagery of northern Italy and the method presented could be extended to the other large (relative to the spatial resolution of the remote scanner that is) lakes of the subalpine region, where visibilities ranges are provided by airports or Aero net stations (Giardino et al. 2007). An onerous activity needs, however, to be completed mainly to assess the lakes' Specific Inherent Optical Properties (SIOPs).

\section{Water Quality Index}

Alboidy et al. (2010) evaluated the historical changes in water quality of Dokan Lake. For this purpose, ten water quality parameters have been selected which are: $\mathrm{pH}$, dissolved oxygen, turbidity, conductivity, hardness, alkalinity, sodium, biochemical oxygen demand, nitrate and nitrite. Values used for each parameter are the mean value of the three sites under this investigation.

The calculation and formulation of the WQI involved the following steps:

1. In the first step, each of the ten parameters has been assigned a weight $\left(\mathrm{AW}_{i}\right)$ ranging from 1 to 4 depending on the collective expert opinions taken from different previous studies. The mean values for the weights of each parameter. However, a relative weight of 1 was considered as the least significant and 4 as the most significant.

2. In the second step, the relative weight (RW) was calculated using the following equation:
$\mathrm{RW}=\mathrm{AW}_{i} / \sum_{i=1}^{n} \mathrm{AW}_{i}$

where RW is the relative weight, AW is the assigned weight of each parameter, $n$ is the number of parameters.

3. In the third step, a quality rating scale $\left(Q_{i}\right)$ for all the parameters except $\mathrm{pH}$ and DO was assigned by dividing its concentration in each water sample by its respective standard according to the drinking water guideline recommended by the, or the Iraqi drinking water standards, the result was then multiplied by 100 .

$Q_{i}=C_{i} / S_{i} \times 100$

While, the quality rating for $\mathrm{pH}$ or $\mathrm{DO}(\mathrm{QpH}, \mathrm{DO})$ was calculated on the basis of,

$\mathrm{QpH}, \mathrm{DO}=\left[C_{i}-V_{i} / S_{i}-V_{i}\right] \times 100$

where $Q_{i}$ is the quality rating, $C_{i}$ is value of the water quality parameter obtained from the laboratory analysis, $S_{i}$ is value of the water quality parameter obtained from recommended WHO or Iraqi standard of corresponding parameter, $V_{i}=$ the ideal value which is considered as 7.0 for $\mathrm{pH}$ and 14.6 for DO. Equations (2) and (3) ensure that $Q_{i}=0$ when a pollutant is totally absent in the water sample and $Q_{i}=100$ when the value of this parameter is just equal to its permissible value. Thus, the higher the value of $Q_{i}$ is, the more polluted is the water.

4. Finally, for computing the WQI, the sub-indices $\left(\mathrm{SI}_{i}\right)$ were first calculated for each parameter and then used to compute the WQI as in the following equations:

$\mathrm{SI}_{i}=\mathrm{RW} \times \mathrm{Q}_{i}$

$\mathrm{WQI}=\sum_{i=1}^{n} \mathrm{SI}_{i}$

The computed WQI values could be classified as $<50=$ Excellent $; \quad 50-100=$ Good $; \quad 100-200=$ Poor; 200-300 = Very poor; $>300=$ Unsuitable.

The WQI was used to aggregate diverse parameters and their dimensions into a single score, displaying a picture of the historical water quality of Dokan Lake. It was observed from the computed annual WQI that the values ranged from 53.18 during 2000 to 101.26 during 2009 and, therefore, can be categorized into "Good water" during 1978, 1979, 1980, 1999, 2000 and 2008 to "Poor water" during 2009. However, it was generally observed that 14 , 80.50 and $5.50 \%$ of all monthly computed WQI values from 1978 to 2009 have fallen under "Excellent", "Good", "Poor", water quality respectively. Unpolluted waters are likely to have a BOD value of $<3 \mathrm{mg} / \mathrm{L}$, while values above $5.0 \mathrm{mg} / \mathrm{L}$ recorded in Dokan lake (only in April 1980) indicate possible pollution (Alboidy et al. 2010). The correlation coefficient between WQI and BOD $(r=0.55)$ 
in the study has shown a significant positive relationship $(P<0.01)$. BOD values indicate a possibility of organic pollution effect on water in this area. The correlation coefficient between WQI and turbidity $(r=0.62)$ showed a significant positive relationship $(P<0.01)$.

\section{Hazard quotient}

Hazard quotients (HQs) were calculated as the ratio of the maximum reported concentration of a contaminant measured in the Great Lakes Basin and either the corresponding available environmental guideline or a benchmark derived from the available toxicity literature. For HQs based on an older existing guideline, a review was carried out to determine whether a more stringent benchmark should be considered. If so, the new benchmark was adopted/set and used for the HQ calculation (Hull et al. 2015)

Hazard quotient $(\mathrm{HQ})=$ maximum reported concentration in water and or sediment/Environmental guideline or derived benchmark.

For those chemicals with an $\mathrm{HQ}>1$, a more detailed analysis of the number and location of exceedances and sources of the chemicals were carried out.

Researchers studied about Great Lakes Basin that riskbased screening of chemicals of emerging concern in Great Lakes water and sediment may be conducted using a variety of methods, most of which use monitoring data and observed or predicted toxicity information. Policy decisions influence methods such as the use of maximum versus mean or median concentrations, low-effect versus no-effect toxicity benchmarks, the magnitude of application factors and the acceptable HQ (e.g. 1.0 versus 0.1 ). The extent of the potential impacts to aquatic populations and communities is not well known, due to gaps in the monitoring data (over both space and time, insufficient analytical methods and detection limits, etc.) and an incomplete understanding of how some of these chemicals affect aquatic organisms either singly or in combination with other toxic compounds.

\section{Harmful algal blooms}

Harmful algal blooms (HABs) in freshwater systems are quickly becoming a global epidemic. An HAB in Lake Erie during the summer of 2014 resulted in a three-day tap water ban for Toledo, Ohio, providing an acute reminder of the impacts of HABs and the urgency of addressing their proliferation. The biogeochemical processes controlling the global increase in HABs are the topic of extensive ongoing research. Much of the debate has centred on HABs in marine ecosystems and similar stressors apply in freshwater systems (Western 2001). Four main hypotheses for the apparent increase have emerged: increased scientific awareness of toxic species, increased anthropogenic nutrient loading, increased frequency and magnitude of extreme climatic events and increased exposure to invasive species. Understanding the role of each of these mechanisms in explaining global HAB trends is an ongoing area of research.

In Lake Erie, the primary species of concern is $\mathrm{Mi}$ crocystis aeruginosa, known for its secretion of the Hepatotoxin microcystin, its use of buoyancy to outcompete other species. Although other harmful species have also been observed in Lake Erie, e.g., APHAnizomenon spp., Anabaena spp., Cylindrospermopsis spp. and Planktothrix spp., Microcystis has been the dominant species in HABs at least since the mid-1990s (Jeff and Michalak 2015). HABs dominated by cyanobacteria (cyanoHABs) such as Microcystis are especially relevant for study as they are rapidly proliferating globally (Backer 2002). In Lake Erie (Jeff and Michalak 2015), it would be problematic, along with the thresholds for dichotomization associated with each, led to different prescriptions for a bloom having occurred, especially because such designations are often used to inform further analysis. In Lake Erie, HAB presence is usually assessed on an annual basis, with blooms typically occurring in late summer after the spring precipitation brings nutrients into the lake. In the years where there is consensus, cyanobacteria are typically either close to completely absent or relatively abundant, resulting in measurements either far below or far above the thresholds for harm. Of the years with mixed evidence, however, measurements near the "bloom" thresholds shed insight on distinctions between methods. In particular, 2002 and 2004 highlight important distinctions in the results from different system.

Overall, the case of Lake Erie finds that there are significant challenges in tracking harmful algal blooms, stemming from the difficulty in comparing results across a diverse set of metrics. Although the analysis conducted here applies most directly to freshwater cyanobacterial HABs, the identified challenges largely also apply to other systems and other types of HABs. Addressing these challenges by better understanding the interplay between different metrics is necessary for tackling more complex questions about the causes and future of HABs, thereby providing a path towards halting and hopefully reversing, the trend towards more frequent and intense HABs globally (Jeff and Michalak 2015). 


\section{Conclusion}

In the present investigation, we reviewed that due to presence of impurities in the lake, there are many different parameters found to be increased during summer season and have got diluted during rainy season. So, this kind of changes would affect the aquatic environment as increase in nitrogen content would result in eutrophication naturally which leads to decrease in the oxygen content level. Lack of oxygen can cause fish kills and lack of fish enables malaria-hosting mosquitoes as mosquitoes are natural food for fish. Without oxygen at the bottom at all times, beneficial bacteria and insects cannot biodegrade the organic sediment at bed level of the lake. Purification methods should exist from filtration processes that should be carried out before introducing any foreign material into the water body. Some pollutants are released into the lake. Proper bioremediation techniques should also be used to improve that water quality. The seasonal values of WQI indicate that during summer season, lake water is more affected than during winter. This could be due to the fact that the microbial activity get reduced due to low temperature, thereby keeping DO level at a very satisfactory range during entire winter season.

The suggested measures to improve the lake water quality include total ban on the activities that cause pollution. The effects of climate change need to be considered in tandem with atmospheric pollution policies. Carbon removal technologies at power stations utilize amines, which could increase ammonia releases, thereby enhancing $\mathrm{N}$ deposition and, hence, both eutrophication and acidification. Idol immersion has major impact on water quality and fishes in lakes particularly concerning heavy metals. Heavy metal concentrations in lake water and muscles of many fishes increased after immersion of idols compared with the maximum permissible concentrations for human intake. Humans are exposed to these accumulated metals in fish by ingestion and can impose higher risks of human health because fishes are found virtually everywhere in the aquatic environment and they play a major ecological role in the aquatic food webs because of their function as a carrier of energy from lower to higher trophic levels. It is further recommended that a real assessment of the water demand for human consumption and the minimum water based on the ecological requirements of floodplains should be undertaken at regular intervals to harness the benefits accrued through their natural function. Discharge of untreated domestic sewage and industrial effluents, washing clothes, vehicles, animals and immersion of idols at the time of festivals contributing to the pollution of lake. The present review reveals that nutrient loading has exceeded the eutrophic condition leading to a hyper eutrophic status.
Land use change and longer growing seasons could increase the use of fertilizers with subsequent leaching to watercourses, rivers and lakes, increasing the risk of eutrophication and loss of biodiversity.

\section{References}

Abboud (2014) Describe and statistical evaluation of hydrochemical data of Karst phenomena in Jordan: Al-Dhaher Cave Karst Spring. IOSR J Appl Geol Geophys (IOSR-JAGG) 2(3):23-42 (e-ISSN: 2321-0990, p-ISSN: 2321-0982)

Abid, Alboidy, Maulood (2010) Application of water quality index for assessment of Dokan lake ecosystem, Kurdistan region, Iraq. J Water Resour Prot: 792-798. doi:10.4236/jwarp.2010.29093

Andrady AL (2011) Microplastics in the marine environment. Mar Pollut Bull 62:1596-1605

APHA (American Public Health Association) (2005) Standards methods for the examination of water and wastewater, 21st edn. American Public Health Association, Washington DC

Arthur C, Baker J, Bamford H (eds) 2009. In: Proceedings of the International Research Workshop on the occurrence, effects, and fate of microplastic marine debris. Tacoma, WA

Backer (2002) Cyanobacterial algal blooms developing a public health response. Lake Reserv Manag 18(1):20-31

Bittner GD, Yang CZ, Stoner MA (2014) Estrogenic chemicals often leach from BPA-free plastic products that are replacements for BPA-containing polycarbonate products. Environ. Health 13:41-54

Boerger CM, Lattin GL, Moore SL, Moore CJ (2010) Plastic ingestion by planktivorous fishes in the North Pacific Central Gyre. Mar Pollut Bull 60:2275-2278

Chandra S, Kumar A, Tomar PK (2012) Assessment of water quality values in Porur Lake Chennai, Hussain Sagar Hyderabad and Vihar Lake Mumbai, India. Chem Sci Trans 1(3):508-515. doi:10.7598/cst2012.169

Chapman (1996) Water quality assessments—a guide to use of biota, sediments and water in environmental monitoring, 2nd edn, ISBN 0419215905 (HB) 0419216006 (PB)

Chaudhry P, Sharma MP, Bhargave R, Kumar S, Dadhwal PJS (2013) Water quality assessment of Sukhna Lake of Chandigarh City of India. Hydro Nepal 12:26-31

Cheng X, Shi H, Adams CD, Ma Y (2010) Assessment of metal contaminations leaching out from recycling plastic bottles upon treatments. Environ Sci Pollut Res Int 17:1323-1330

Driedger AGJ, Dürr HH, Mitchell K, VanCappellen P (2015) Plastic debris in the Laurentian Great Lakes: a review. J Great Lakes Res 41:9-19

Eriksen M, Mason S, Wilson S, Box C, Zellers A, Edwards W, Farley $\mathrm{H}$, Amato S (2013) Microplastic pollution in the surface waters of the Laurentian Great Lakes. Mar Pollut Bull 77:177-182

Fakioglu O (2013) Phytoplankton biomass impact on the lake water quality. doi:10.5772/55361

Giardino C, Brando VE, Dekker AG, Strömbeck N, Candiani G (2007) Assessment of water quality in Lake Garda (Italy) using Hyperion, remote sensing of environment, 183-195. http://www. sciencedirect.com

Gupta, Paul M (2010) The seasonal variation in ionic composition of pond water of Lumding, Assam, India. doi:10.12944/ CWE.8.1.12

Hoellein T, Rojas M, Pink A, Gasior J, Kelly J (2014) Anthropogenic litter in urban freshwater ecosystems: distribution and microbial interactions 
Hull, Kleywegt S, Schroeder J (2015) Risk-based screening of selected contaminants in the Great Lakes Basin. J Great Lakes Res 41(2015):238-245

Jeff, Michalak (2015) Challenges in tracking harmful algal blooms: a synthesis of evidence from Lake Erie. J Great Lake Res 41(2):317-325. doi:10.1016/j.jglr.2015.01.001

Mackay AW, Ryves DB, Morley DW, Jewson DH, Rioual P (2006) Assessing the vulnerability of endemic diatom species in Lake Baikal to predicted future climate change: a multivariate approach. Glob Change Biol 12:2297-2315. doi:10.1111/j. 1365-2486.2006.01270.x

Meeker JD, Sathyanarayana S, Swan SH (2009) Phthalates and other additives in plastics: human exposure and associated health outcomes. Phil Trans R Soc B 364:2097-2113

Penn, Pauer, Mihelcic (2003) Environmental and ecological chemistry, vol 2

Rochman CM, Hoh E, Kurobe T, Teh SJ (2013) Ingested plastic transfers hazardous chemicals to fish and induces hepatic stress. Sci Rep 3:1-7

Ryan P (1988) Marine litter keeps increasing. Nature 361:23

Shah AA, Hasan F, Hameed A, Ahmed S (2008) Biological degradation of plastics: a comprehensive review. Biotechnol Adv 26:246-265

Spellman (2014) Handbook of water and wastewater treatment plant operations, 3rd edn. Taylor and Francis group, ISBN: 978-14665-5385-5
Spellman FR, Drinan JE (2012) The drinking water handbook, 2nd edn, ISBN: 978-1-4398-6690-0

Teuten EL, Rowland SJ, Galloway TS, Thompson RC (2007) Potential for plastics to transport hydrophobic contaminants. Environ Sci Technol 41:7759-7764

Wagner M, Scherer C, Alvarez-Muñoz D, Brennholt N, Bourrain X, Buchinger S, Fries E, Grosbois C, Klasmeier J, Marti T, Rodriguez-Mozaz S, Urbatzka R, Vethaak A, Winther-Nielsen M, Reifferscheid G (2014) Microplastics in freshwater ecosystems: what we know and what we need to know. Environ Sci Eur 26:12

Western (2001) Human-modified ecosystems and future evolution 98(10):5458-5465. doi:10.1073/pnas.101093598

Wetzel RG (2001) Limnology. Academic Press, London, p 1006

Williams RJ, White C, Harrow M, Neal C (2000) Temporal and small-scale spatial variations of dissolved oxygen in the rivers Thames, Pang and Kennet. Sci Total Environ 251(252):497-512

Wright SL, Thompson RC, Galloway TS (2013) The physical impacts of microplastics on marine organisms: a review. Environ Pollut 178:483-492

Zbyszewski M, Corcoran PL, Hockin A (2014) Comparison of the distribution and degradation of plastic debris along shorelines of the Great Lakes, North America. J Great Lakes Res 40:288-299 